\title{
Variability in Ribosomal DNA Genic and Spacer Regions in Verticillium dahliae Isolates from Different Hosts
}

\author{
Laura Otero ${ }^{1}$, Daniel Ducasse ${ }^{2} \&$ Robert N. G. Miller $^{3}$ \\ ${ }^{1}$ Inst. Fitopatología y Fisiología Vegetal IFFIVE-INTA. Cam. A. 60 Cuadras Km. 5 1/2 (5119) Córdoba, Argentina, \\ e-mail: lotero@correo.inta.gov.ar; ${ }^{2}$ Univ. Católica de Córdoba, Córdoba, Argentina; ${ }^{3}$ Pós-graduação em Ciências \\ Genômicas e Biotecnologia, Universidade Católica de Brasília, Campus II - SGAN 916, CEP 70790-160, \\ Brasília, DF, Brazil, Fax: (61) 347-4797, e-mail: rmiller@pos.ucb.br
}

(Aceito para publicação em 16/02/2004)

Corresponding author: Robert N. G. Miller

OTERO, L., DUCASSE, D. \& MILLER, R.N.G. Variability in ribosomal DNA genic and spacer regions in Verticillium dahliae isolates from different hosts. Fitopatologia Brasileira 29:441-446. 2004.

\begin{abstract}
Using PCR-based assays with specific primers for amplification of the ribosomal DNA intergenic spacer region (IGS) and a portion of the mitochondrial DNA small subunit ribosomal RNA gene (mtDNA SSU rRNA), the genetic variability among Verticillium dahliae isolates from olive (Olea europaea) and other host species from Argentina and Brazil was estimated. The derived UPGMA-generated phenograms based upon the restriction fingerprinting data of rDNA IGS products revealed genetic differences, correlating with the host of origin. Isolates infecting olive genetically distinct from those from cocoa (Theobroma cacao)

and sunflower (Helianthus annuus). Digestion of mitochondrial DNA SSU rRNA PCR products revealed less variability, distinguishing only one isolate from sunflower. Ribosomal DNA ITS restriction patterns were identical for all isolates of $V$. dahliae, irrespective of host of origin. These preliminary results may have relevance for Verticillium wilt control practices, possibly reflecting a different evolutionary origin, or reproductive isolation of the pathogen in olive, distinct from populations of other hosts.

Additional keywords: Olea europaea, molecular markers, characterization.

\section{RESUMO}

Variabilidade de regiões gênicas e espaçadoras do DNA ribossomal de Verticillium dahliae isolados de hospedeiros diferentes

A variabilidade genética de isolados de Verticillium dahliae oriundos de oliveira (Olea europaea) e de outros hospedeiros na Argentina e Brasil foi estimada através de PCR, usando primers específicos para a amplificação da região espaçadora intergênica do DNA ribossomal (IGS) e de uma porção do gene codificante para a subunidade menor do RNA ribossomal do DNA mitocondrial (mtDNA SSU rRNA). Os fenogramas gerados usando UPGMA, baseados em perfis de restrição da região IGS do rDNA revelaram diferenças genéticas, correlacionadas ao hospedeiro de origem, com isolados originados de oliveira geneticamente distintos daqueles

que infetam cacau (Theobroma cacao) e girassol (Helianthus annuus). A digestão dos produtos de PCR do SSU rRNA do DNA mitocondrial revelou menor variabilidade, distinguindo somente um isolado de girassol dos demais. Padrões de restrição da região ITS do rDNA nuclear apresentaram-se idênticos para todos os isolados de $V$. dahliae, independente de hospedeiro de origem. Estes resultados preliminares podem ter relevância para o desenvolvimento de estratégias de controle das murchas causadas por $V$. dahliae, possivelmente refletindo uma origem evolucionária diferente, ou isolamento reprodutivo do patógeno causador da murcha em oliveira, que se apresentou distinto de populações originárias de outros hospedeiros.
\end{abstract}

Olive (Olea europaea L.) cultivars in the Argentinian provinces of Cordoba, Catamarca and La Rioja are susceptible to verticillium wilt caused by the hyphomycete fungal pathogen Verticillium dahliae Kleb. The impact of the disease has not yet been fully estimated, although its potential is obvious, given previous reports showing an incidence of up to $70 \%$ in other countries. Symptoms comprise a progressive wilt of the tree, reducing productivity, and eventually leading to death. Individual branches can be affected, with brown discolouration of leaves, leaf curling and adherence. A generalised practice among producers is to continually remove dry branches. This labour intensive approach can enable the tree to recover during leaf budding, although the disease will generally continue until plant death. Verticillium dahliae is distributed worldwide, and is pathogenic to a wide range of crops, from fruit crops and vegetables to forest trees. Classification of species is controversial, and differentiation relies on morphological characteristics, such as conidial form, growth on semi-selective media, vegetative compatibility, cultural characters, and biochemical characteristics. Host specific isolates cannot be differentiated on the basis of morphology, and intraspecific identification is reliant upon pathogenicity tests using differential hosts. Such approaches, however, are time consuming and often insufficient for intraspecific differentiation. Verticillium dahliae is considered to lack host specificity, such that formae speciales and races are rarely described. Limited information is available regarding variability in $V$. dahliae causing verticillium wilt in 
olive. As olive can be intercropped with species such as sunflower (Helianthus annuus L.), cotton (Gossypium hirsutum L.), tomato (Lycopersicon esculentum Mill.) and cocoa (Theobroma cacao L.), pathogen host specificity requires resolution for choice of crops for rotation, and for development of disease control strategies.

Phylogenetic analysis within the genus, based upon ribosomal DNA gene and spacer region sequences, has suggested that the genus Verticillium is polyphyletic in origin, and that morphological characters are not accurate indicators of phylogenetic relatedness. Ribosomal DNA has an important function in terms of protein synthesis, and variability may reflect genomic evolution. In fungi, rDNA gene and spacer regions have been extensively applied in discrimination from generic to intraspecific levels. The ITS region has been used for distinction and primer design for detection of $V$. dahliae and V. albo-atrum Reinke and Berth. (Nazar et al., 1991; Hu et al., 1993). The IGS spacer region is less conserved and more appropriate for intraspecific discrimination. Such variability in the IGS region has been reported in $V$. dahliae (Pramateftaki et al., 2000). Extra chromosomal genetic information can be useful for clarification of taxonomic positions and pathogen identities. Mitochondrial genomes contain genes coding for mitochondrial proteins, as well as all tRNAs, and large and small subunits of rRNA (LSU and SSU rRNAs). Given that the mitochondrial rRNA genes have been reported to evolve in fungi up to 16 times faster than nuclear rDNA, inter and intra-specific variation may potentially be detected. The RFLP analysis of a region of the mtDNA SSU rRNA gene also differentiated ten species of Verticillium, and enabled design of specific primers for $V$. dahliae (Li et al., 1994).

During part of a three-year study of the variability of $V$. dahliae in olive growing regions in Argentina, we compared the nuclear rDNA ITS and IGS region, and the mtDNA SSU rRNA gene to determine genetic diversity in olive populations, and their relationship to isolates from other susceptible hosts commonly intercropped with olive, in order to identify hostadapted pathotypes within $V$. dahliae. An understanding of genetic variability in populations of $V$. dahliae is of fundamental importance for developing effective control strategies of verticillium wilt, especially in relation to use of representative pathogen genotypes in national resistance breeding programs.

Isolates were obtained from olive in the northwest region of Argentina, as well as from comparative isolates of sunflower. Additional comparative isolates from cocoa (provided by the Plant Pathology Department, University of Brasilia) and Gossypium hirsutum (ATCC, USA) were also included in molecular analyses (Table 1). Single spore cultures were grown on acidified potato dextrose agar medium and stored on potato-dextrose agar (PDA) slants at $4{ }^{\circ} \mathrm{C}$. Isolate identification to species level was conducted according to Presley (1969) and Schanathorst (1971). Typical colony morphology and dark microsclerotia were observed in all $V$. dahliae isolates, conforming to typical descriptions (Klebahn, 1913). Pathogenicity was assayed for all isolates from olive, according to Schanathorst (1971), through inoculation into four cotton varieties with differential degrees of tolerance to $V$. dahliae. The DNA was extracted from $50 \mathrm{mg}$ fungal biomass from 14 day old Czapex broth liquid cultures, using a standard CTAB maxi-prep method. The DNA concentrations were determined by visual comparison on ethidium bromide stained gels of total DNA and High DNA Mass Ladder fragments (Gibco BRL Ltd), and concentrations adjusted to between 15 and $40 \mathrm{ng} / \mu \mathrm{l}$.

The rDNA ITS regions were amplified with the primer pair ITS1/ITS4 as described by White et al. (1990). Following an initial screening of candidate restriction enzymes, digestion of amplification products was performed using the restriction enzymes DdeI and HinfI (Gibco-BRL Ltd), according to manufacturer's instructions. For all molecular markers examined, digested and undigested PCR products were separated by electrophoresis in $1.5 \%$ agarose, using $1 \mathrm{x}$ TAE buffer, and product sizes calculated by comparison to standard $1 \mathrm{~Kb}$ or 100 bp DNA molecular weight markers (Gibco BRL Ltd). The rDNA IGS spacer region was amplified using the flanking primer pair CNL12 and CNS1 (White et al., 1990), which anneal to the extremities of the 28S and 18S rRNA genes. PCR amplification was conducted using an MJ Research PCT-100 thermocycler, with the following program: a single denaturation step at $95^{\circ} \mathrm{C}$ for $2 \mathrm{~min}, 14$ cycles of denaturation at $95{ }^{\circ} \mathrm{C}$ for $45 \mathrm{~s}$, primer annealing at $59.3{ }^{\circ} \mathrm{C}$ for $1 \mathrm{~min}$, and extension at $72{ }^{\circ} \mathrm{C}$ for $45 \mathrm{~s}, 16$ cycles of denaturation at $95{ }^{\circ} \mathrm{C}$ for $45 \mathrm{~s}$, primer annealing at $59.3{ }^{\circ} \mathrm{C}$ for $1 \mathrm{~min}$, and extension at $72{ }^{\circ} \mathrm{C}$ for $2 \mathrm{~min}, 15$ cycles of denaturation at $95{ }^{\circ} \mathrm{C}$ for $45 \mathrm{~s}$, primer annealing at $59.3{ }^{\circ} \mathrm{C}$ for $1 \mathrm{~min}$, and extension at $72{ }^{\circ} \mathrm{C}$ for $3 \mathrm{~min}$, and a final extension step of $72{ }^{\circ} \mathrm{C}$ for $10 \mathrm{~min}$. Each $25 \mu 1$ PCR reaction mixture contained $0.5 \mu \mathrm{M}$ of each primer, $200 \mu \mathrm{M}$ dNTPs (Gibco-BRL Ltd), $1.5 \mathrm{mM} \mathrm{MgCl}$ (Gibco-BRL Ltd), $1.25 \mathrm{U}$ Taq DNA polymerase (Gibco-BRL Ltd), and approximately 15 - 40 ng genomic DNA. Following initial screenings for restriction sites, amplification products were subsequently digested with the restriction enzymes $M s p \mathrm{I}, \operatorname{Hinf} \mathrm{I}, E c o R \mathrm{I}$, PstI (Gibco-BRL Ltd), as described for ITS RFLPs.

A sequence of the mtDNA SSU rRNA gene was amplified using the primer pair MS1 and MS2 (White et al., 1990). Amplification conditions comprised an initial denaturation step of $94^{\circ} \mathrm{C}$ for $4 \mathrm{~min}$, followed by 35 cycles of denaturation at $92^{\circ} \mathrm{C}$ for $2 \mathrm{~min}$, primer annealing at 48.3 ${ }^{\circ} \mathrm{C}$ for $1 \mathrm{~min}$, and extension at $72{ }^{\circ} \mathrm{C}$ for $1 \mathrm{~min}$, and a final extension step at $72{ }^{\circ} \mathrm{C}$ for 5 min. Each $25 \mu 1$ volume PCR reaction mixture each contained $0.5 \mu \mathrm{M}$ of each primer, 200 $\mu \mathrm{M}$ dNTPs, $1.5 \mathrm{mM} \mathrm{MgCl}, 1.25 \mathrm{U}$ Taq DNA polymerase, and again between $15-40 \mathrm{ng}$ genomic DNA. Following an initial screening, restriction enzymes $D r a \mathrm{I}$ and $R s a \mathrm{I}$ were subsequently identified for digestion of PCR products.

The PCR RFLP band sizes were converted into binary data and used to determine similarities between isolates (using Sorenson's Coefficient). Data were subsequently clustered by UPGMA (unweighted paired-group method using arithmetic means), with calculations undertaken using the software 
Variability in ribosomal DNA genic and spacer regions in...

TABLE 1 - Species designation, origin, pathogenicity status, mtDNA SSU rRNA and rDNA IGS RFLP groupings of Verticillium dahliae

\begin{tabular}{|c|c|c|c|c|c|c|c|c|c|c|c|}
\hline \multirow{3}{*}{ Isolate identity } & \multirow{3}{*}{ Species } & \multirow{3}{*}{$\begin{array}{l}\text { Country of } \\
\text { origin }\end{array}$} & \multirow{3}{*}{ Locality } & \multirow{3}{*}{ Plant Host } & \multirow{3}{*}{ Symptom* } & \multicolumn{6}{|c|}{ RFLP group } \\
\hline & & & & & & \multicolumn{2}{|c|}{$\begin{array}{c}\text { MtDNA SSU } \\
\text { rRNA }\end{array}$} & \multicolumn{4}{|c|}{ rDNA IGS } \\
\hline & & & & & & ${ }^{\mathrm{A}}$ DraI & ${ }^{\mathrm{B}} \mathrm{RsaI}$ & ${ }^{\mathrm{C}}$ EcoRI & ${ }^{\mathrm{D}}$ HinfI & ${ }^{\mathrm{E}} \mathrm{MspI}$ & ${ }^{\mathrm{F} P \text { stI I }}$ \\
\hline M1 & $\begin{array}{l}\text { Verticillium } \\
\text { dahliae }\end{array}$ & Argentina & La Rioja & Olea europaea & $\begin{array}{l}\text { chlorosis } \\
\text { and wilt }\end{array}$ & 1 & 1 & 1 & 1 & 1 & 1 \\
\hline M9 & V. dahliae & Argentina & La Rioja & O. europaea & $\begin{array}{l}\text { chlorosis } \\
\text { and wilt }\end{array}$ & 1 & 1 & 1 & 1 & 1 & 1 \\
\hline M25 & V. dahliae & Argentina & La Rioja & O. europaea & $\begin{array}{l}\text { chlorosis } \\
\text { and wilt }\end{array}$ & 1 & 1 & 1 & 1 & 1 & 1 \\
\hline M27 & V. dahliae & Argentina & LaRioja & O. europaea & $\begin{array}{l}\text { chlorosis } \\
\text { and wilt }\end{array}$ & 1 & 1 & 1 & 1 & 1 & 1 \\
\hline MAMERICA & V. dahliae & Argentina & Site Bs.As & Helianthus annuus & - & 2 & 2 & 4 & 2 & 2 & 2 \\
\hline TRES ARROYOS & V. dahliae & Argentina & Site Bs.As & H. annuus & - & 1 & 1 & 2 & 3 & 3 & 1 \\
\hline M23 & V. dahliae & Brazil & $\begin{array}{l}\text { Floresta Azul, } \\
\text { Bahia }\end{array}$ & Theobroma cacao & - & 1 & 1 & 3 & 4 & 4 & 3 \\
\hline M24 & V. dahliae & Brazil & $\begin{array}{l}\text { Floresta Azul, } \\
\text { Bahia }\end{array}$ & T. cacao & - & 1 & 1 & 3 & 5 & 4 & 3 \\
\hline $\mathrm{T} 1$ & V. dahliae & USA & Unknown & Gossypium hirsutum & - & 1 & 1 & 1 & 6 & 3 & 1 \\
\hline
\end{tabular}

${ }^{\text {A}}$ Mt DNA SSU rRNA DraI - RFLP group fragment sizes (bp): 1- 380; 120; 2- 350, 200

${ }^{\mathrm{B}}$ Mt DNA SSU rRNA RsaI RFLP group fragment sizes (bp): 1: 300, 230; 2- 500

CIGS EcoRI RFLP group fragment sizes (bp): 1 - 1000, 200; 2 - 1000, 650, 400, 200; $3-800,650,400,200,4-2200$ (undigested).

DIGS Hinfl RFLP group fragment sizes (bp): 1 - 700, 500, 300, 200; 2 - 400, 250; $3-700,500,350,200 ; 4-500,450,350,200 ; 5-850,500,450,350,200$; $6-600,500,300,200$

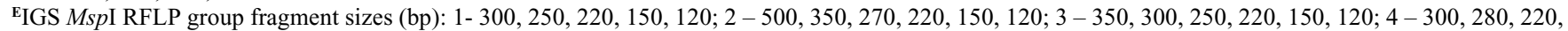
150,120

FIGS PstI RFLP group fragment sizes (bp): 1- 1500, 700, 180, 150; 2 - 2200 (undigested); 3 - 1150, 700, 180, 150

*Symptoms observed on cotton, via artificial inoculation

package MVSP (Kovach Computing Services, Anglesey, UK). All isolates were identified as $V$. dahliae based upon morphological characteristics and the presence of microsclerotia. Isolates from olive were all pathogenic on cotton, and characterized as non-defoliating, producing mild symptoms of chlorosis and wilt.

Specific PCR amplification of the rDNA ITS regions produced a product $330 \mathrm{bp}$ in size, for all isolates of $V$. dahliae examined. Comparison of restriction sites using endonucleases DdeI and Hinfl revealed identical RFLP profiles in all cases (data not presented).

Amplification of the nuclear rDNA IGS spacer region yielded a single PCR product of approximately $2200 \mathrm{bp}$ for all isolates. Phenetic analyses were conducted individually for each restriction enzyme used (data not shown) and on combined PCR-RFLP data (Figure 1C). Analysis of EcoRI RFLP data (Table 1, Figure 1A) revealed four haplotypes among the isolates, with a uniformity in RFLP profile for all isolates from olive, which shared an RFLP profile with isolate $\mathrm{T} 1$ from cotton, and additional groupings of isolates from sunflower and cocoa. The Hinfl-derived RFLPs produced a total of six haplotypes, with isolates from olive comprising a distinct group (Table 1, Figure 1B). The IGS MspI RFLPs revealed four haplotypes, with a principal group of isolates originating from olive, distinct from isolates from sunflower, cocoa and cotton (Table 1, gel not shown). The IGS PstI RFLPs produced similar groupings to those generated using $E c o$ R1 data, with isolate T1 from cotton, as well as isolate Tres Arroyos from sunflower showing identical RFLP profiles to the isolates from olive (Table 1, gel not shown). The dendrogram based upon combined RFLP data showed a total of six haplotypes (Figure 1C), with isolates from olive clearly distinguished from isolates from cotton, cocoa and sunflower.

Amplification of the mitochondrial DNA SSU rRNA gene produced a single PCR product of approximately 600 bp in all isolates examined. Phenetic analyses of combined RsaI and DraI RFLP data revealed only two haplotypes (Figure $2 \mathrm{~A}$ to $\mathrm{C}$ ), with only one isolate from sunflower genetically distinct on the basis of restriction profiles.

The broad objective of this research was aimed towards a clarification of the genetic variability of pathogenic isolates of $V$. dahliae causing wilt in olive, essential for effective germplasm screening in resistance breeding programs, disease management practices such as intercropping and crop rotation, and for molecular diagnostic development. In order to reveal intraspecific variability in $V$. dahliae a number of molecular markers were evaluated, each with different discriminating resolutions. The RFLP analysis of PCR amplified ITS regions did not reveal intraspecific variability in $V$. dahliae isolates. Indeed, previous studies on Verticillium spp. using ITS regions reported its' applicability for interspecies comparisons and molecular detection of $V$. dahliae and V. albo-atrum (Nazar et al., 1991). Adaptation for quantitative analysis using specific PCR primers derived from ITS sequences has also been reported for $V$. albo-atrum and $V$. dahliae in infected plant tissues (Hu et al., 1993). Intraspecific variability in ITS sequences within $V$. dahliae appears to be very limited. For instance, Morton et al. (1995a) 

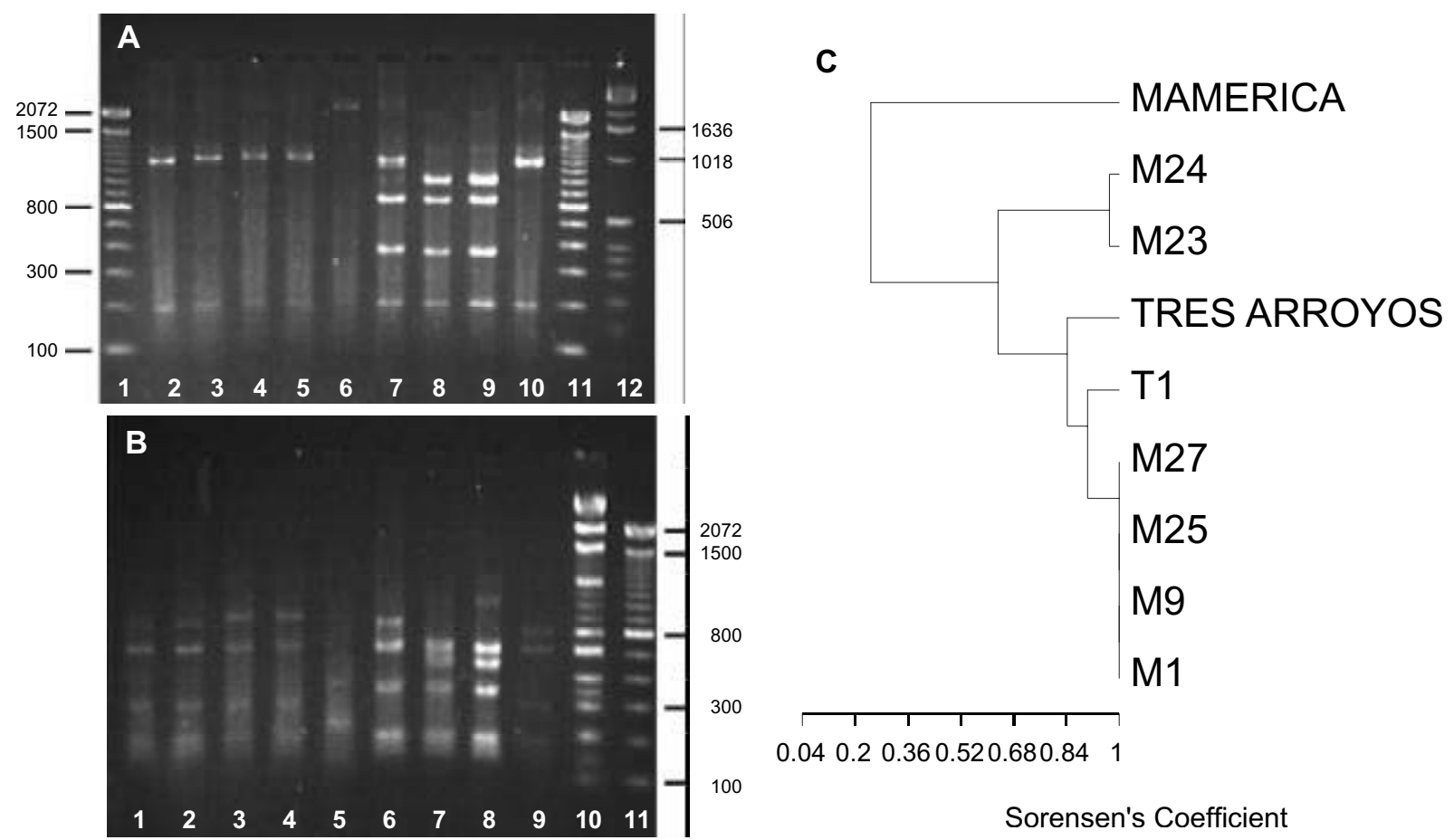

FIG. 1 - Ribosomal intergenic spacer region (IGS) restriction fragment length polymorphisms (RFLP) in Verticillium dahliae isolates. (A), EcoR1-digests. Lane 1, 100 bp ladder; lanes 2 to 10 represent isolates M1, M9, M25, M27, America, Tres Arroyos, M23, M24 and T1; lane 11, 100 bp ladder; lane 12, 1 kb ladder. (B), Hinfl-digests. Lanes 1 to 9 represent isolates M1, M9, M25, M27, Mamerica, Tres Arroyos, M23, M24 and T1; lane 10, $1 \mathrm{~kb}$ ladder; lane 11, $100 \mathrm{bp}$ ladder. Numbers on the left and right hand sides of the gel refer to the size (in base pairs) of marker fragments. (C), UPGMA - derived dendrogram of coded combined rDNA IGS EcoRI, HinfI, MspI, and PstI RFLP fragment size data for Verticillium dahliae isolates. The dendrogram was constructed using Sorensen's coefficient.

reported only up to $5 \mathrm{bp}$ differences in 22 haploid strains differing in host range and country of origin, with identical sequences in 4 diploid strains from different hosts and continents. In contrast to V. albo-atrum, where only two host specific intraspecific groups were identified via molecular approaches (Okoli et al., 1993), a greater genetic variation was found in $V$. dahliae populations. Intraspecific variability was previously detected by VCG using $\underline{\text { nit }}$ mutants, with five main groups recognised (Chen, 1994). Unfortunately, although VCG is a stable character for intraspecific differentiation, groups do not appear to be related to pathogenicity to particular host species. Considerable variation within $V$. dahliae was also detected via RAPD analysis, correlating with pathogenicity (Messner et al., 1996). Using random genomic $V$. dahliae probes and southern blotting of RFLPs, Okoli et al. (1993) also observed intraspecific groups, although with no correlation with host plant or geographical origin of isolates. In a later publication (Okoli et al., 1994), the authors reported the same approach as sufficient for differentiating host-adapted pathotypes from peppermint and crucifers. To date, however, there exists little information on genetic diversity and pathogenicity to the wealth of different susceptible hosts within $V$. dahliae.

Short sub-repeat sequences in the IGS region have previously been observed in $V$. dahliae, with differences detected in haploid and diploid strains in terms of sub-repeat length, sufficient to suggest they become separate species (Morton et al., 1995a, b). Different overall IGS sizes were also reported recently by Pramateftaki et al. (2000), observing an IGS size of $1.6 \mathrm{~kb}$ in $31 \mathrm{~V}$. dahliae strains, and $1.7 \mathrm{~kb}$ in another ten $V$. dahliae strains. Such differences were due to the presence of a hot spot region of large insertions. Our results indicate that intraspecific groups within $V$. dahliae correlating with host plants can be discriminated via IGS RFLP-derived polymorphisms. The possibility of correlation with geographical origin seems unlikely, given that the isolates from sunflower from the same locality, as well as the Brazilian isolates from cocoa showed polymorphisms with a number of restriction enzymes employed. In contrast to Pramateftaki et al. (2000), IGS size was constant for all strains examined. Dependent on the restriction enzyme employed, variability in isolates from the same host species was also detected, although without obvious correlation with virulence or geographical origin. To the author's knowledge, no other publication has to date focussed on determining genetic variability between $V$. dahliae isolates from olive, cocoa and sunflower. A previous study by Subbarao et al. (1995) compared rDNA IGS RFLPs in 13 strains from cabbage (Brassica oleraceae L.), cauliflower [Brassica oleracea (L.) var. botrytis], and strawberry (Fragaria ananassa L.). In this 
Variability in ribosomal DNA genic and spacer regions in...
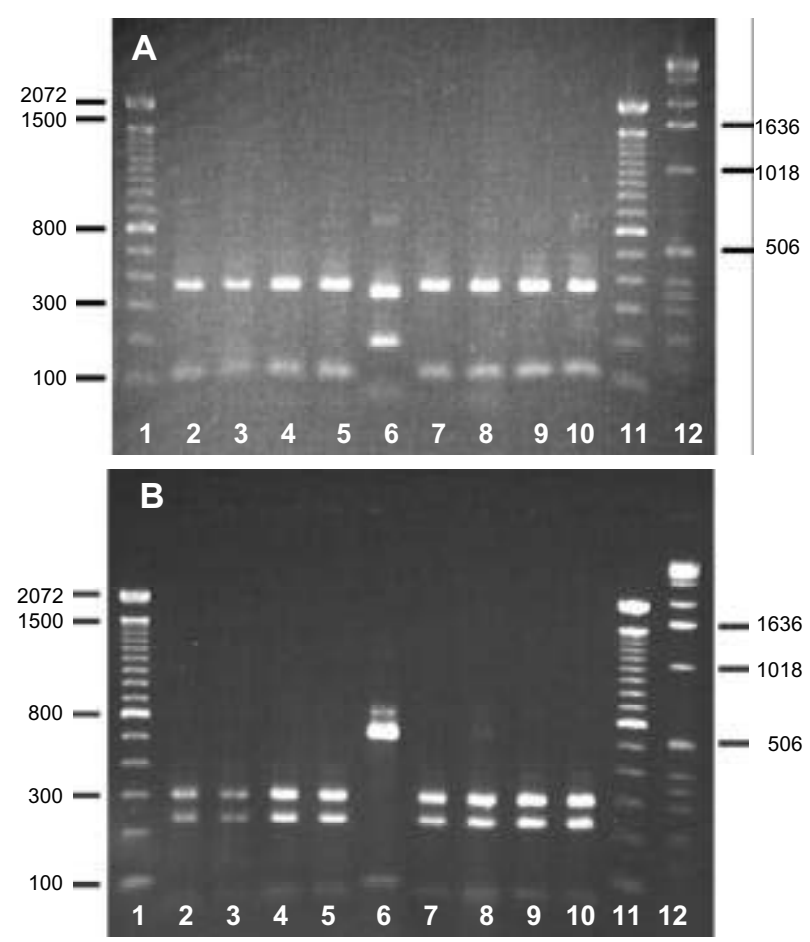

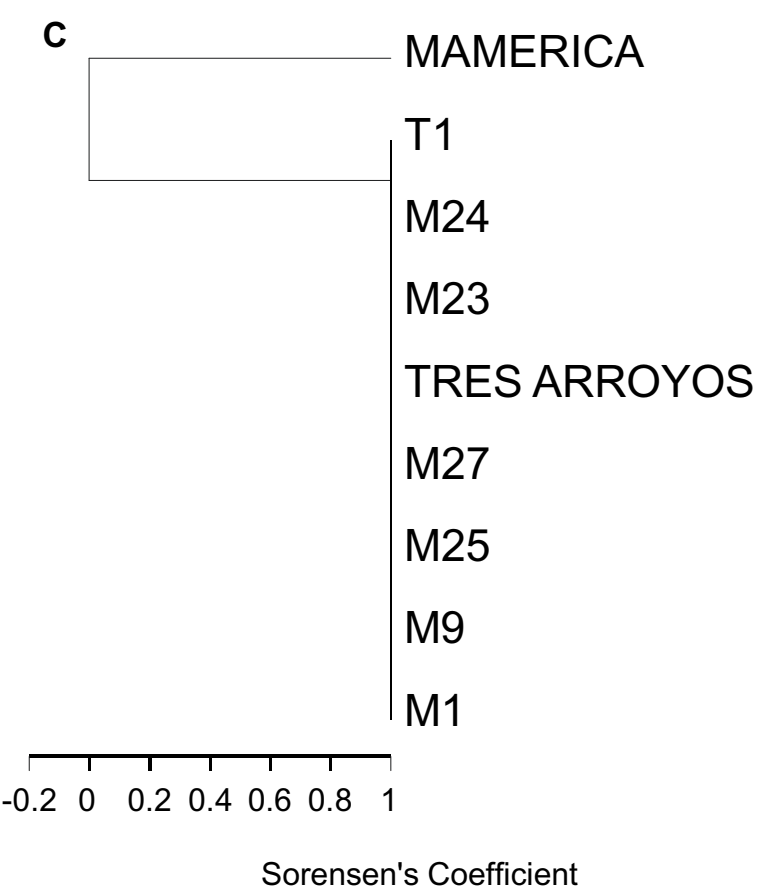

FIG. 2 - mtDNA SSU rRNA RFLPs in Verticillium dahliae isolates. (A), DraI - digests. Lane 1, 100 bp ladder; lanes 2 to 10 represent isolates M1, M9, M25, M27, Mamerica, Tres Arroyos, M23, M24 and T1; lane 11, 100bp ladder; lane 12, 1 kb ladder. (B), RsaI -digests. Lane 1, 100 bp ladder; lane 2, M1; lane 3, M9; lane 4, M25; lane 5, M27; lane 6, Mamerica; lane 7, Tres Arroyos; lane 8, M23; lane 9, M24; lane 10, T1; lane 11, $100 \mathrm{bp}$ ladder; lane 12,1 kb ladder. Numbers on the left and right hand sides of the gel refer to the size (in base pairs) of marker fragments. (C), UPGMA - derived dendrogram of coded combined mtDNA SSU rRNA RsaI and DraI RFLP fragment size data for $V$. dahliae isolates. The dendrogram was inferred using Sorensen's coefficient.

case, more than one IGS haplotype was detected in strains pathogenic to a particular host or pertaining to a VCG group. The presence of two IGS haplotypes in strains from cauliflower contradicted the assumption of a recent introduction of the pathogen to California.

Our study revealed considerable homogeneity in isolates from olive, while different haplotypes were observed in isolates from the other host species evaluated. Such data may indicate a different evolutionary origin of the olive pathogen, possibly due to importation of infected plantlets from Mediterranean countries. However, as shared bands were relatively common, it is also possible that the isolates have a common evolutionary origin. An alternative is that the majority of indigenous isolates in olive may have become reproductively isolated, with selective pressure to conserve genes involved in host specificity towards olive, and restricting continued gene flow with isolates from other hosts. Given that genetic identity was detected in all isolates examined from olive, clonal origin may also be a possibility.

Previous studies using the mtDNA small rRNA gene detected eight Ascomycete genera and ten Verticillium species (Li et al., 1994). This region was also sufficiently conserved to enable development of PCR primers for detection of $V$. dahliae from different countries and plant host species. In our study, RFLP analysis of the mtDNA SSU rRNA gene revealed less variability than in the nuclear IGS region; there was only a single isolate from sunflower that was genetically different in terms of restriction sites, which showed no correlation with virulence or geographical origin. This apparent inapplicability as an intra-specific marker, in contrast to the IGS spacer region, may be due to the fact that this PCR product originates from a conserved coding region. However, given that only two restriction enzymes were used in this analysis, it is possible that further haplotypes may be observed, if additional enzymes are applied in future analyses.

In summary, the genetic differences observed through RFLP analysis of the PCR amplified nuclear rDNA IGS region and mitochondrial SSU rRNA gene indicated intraspecific variability in $V$. dahliae, separating isolates from olive from those in other hosts. Such genetic differences may reflect restriction to particular hosts or even differences in virulence, which in the former case may suggest that the current interplanting practices are not acting as inoculum sources of $V$. dahliae to olive. Further research, using a more representative set of isolates, including cross pathogenicity studies with all isolates, and full length sequencing of PCR products, will be necessary to determine if intraspecific groups continue to correlate with the plant hosts. If so, the observed polymorphism may be employed for development of a 
molecular diagnostic for $V$. dahliae from olive, applicable for pathogen detection in plantlet material or infested soils.

\section{ACNOWLEDGMENTS}

Laboratory equipment for this study was funded through the World Bank / Embrapa Research grant PRODETAB 106-01/98 "Caracterização de isolados de Fusarium solani patogênicos a batata e soja no Brasil e desenvolvimento de métodos para diagnóstico em plantas e sementes". A component of this study was conducted at the Department of Plant Pathology, Universidade de Brasilia, D.F., Brazil.

\section{LITERATURE CITED}

CHEN, W. Vegetative compatibility groups in Verticillium dahliae from ornamental woody plants. Phytopathology 84:214-219. 1994.

HU, X., NAZAR, R.N. \& ROBB, J. Quantification of Verticillium biomass in wilt disease development. Physiological and Molecular Plant Pathology 42:23-26. 1993.

KLEBAHN, H. Beitrage zur kenntnis der fungi iimperfecti. I. Eine Verticillium krantkheit auf dahlien. Mycologisches Centralblatt 3:49 - 66. 1913.

LI, K.N., ROWE, D.I. \& GERMAN, T.I. PCR primers allow intergeneric differentiation of ascomycetes and their application to Verticillium spp. Applied and Environmental Microbiology 60:43244331. 1994.

MESSNER, R., SCHWEIGKOFLER, W., IBL, M., BERG, G. \& PRILLINGER, H. Molecular characterization of the plant pathogen Verticillium dahliae Kleb. using RAPD-PCR and sequencing of the 18S rRNA-gene. Journal of Phytopathology 144:347-354. 1996.

MORTON, A., CARDER, J.H. \& BARBARA, D.J. Sequences of the internal transcribed spacers of the ribosomal RNA genes and relationships between isolates of Verticillium alboatrum and $V$. dahliae. Plant Pathology 44:183-190. 1995a.
MORTON, A., TABRETT, A.M., CARDER, J.H. \& BARBARA, D.J. Sub-repeat sequences in the ribosomal RNA intergenic regions of Verticillium alboatrum and V. dahliae. Mycological Research 99:257266. 1995 b.

NAZAR, R.N., HU, X, SCHMIDT, J., CULHAM, D. \& ROBB, J. Potential use of PCR amplified ribosomal intergenic sequences in the detection and differentiation of Verticillium wilt pathogen. Physiological and Molecular Plant Pathology 39:1-11. 1991.

OKOLI, C.A.N., CARDER, J.H. \& BARBARA, D.J. Molecular variation and sub-specific groupings within Verticillium dahliae. Mycological Research 97:233-239. 1993.

OKOLI, C.A.N., CARDER, J.H. \& BARBARA, D.J. Restriction length polymorphisms (RFLPs) and the relationships of some host adapted isolates of Verticillium dahliae. Plant Pathology 43:33-40. 1994.

PRAMATEFTAKI, P.V., ANTONIOU, P.P. \& TYPAS, M.A. The Complete DNA Sequence of the Nuclear Ribosomal RNA Gene Complex of Verticillium dahliae: Intraspecific Heterogeneity within the Intergenic Spacer Region. Fungal Genetics and Biology 29:1927. 2000 .

PRESLEY, J.T. Growth response of Verticillium albo-atrum to sanguinarine in nutrient agar. Phytopathology 59:1968-1969. 1969.

SCHANATHORST, W.C. \& SIBBET, G. S. The relation of strains of Verticillium alboatrum to severity of Verticillium wilt in Gossypium hirsutum and Olea europaea in California. Plant Disease Reporter 55:780-782. 1971.

SUBBARAO, KV., CHASSOT, A., GORDON, TR., HUBBARD, JC., BONELLO, P., MULLIN, R., OKAMOTO, D., DAVIS, R,M. \& KOIKE, S.T. Genetic relationships and cross pathogenicities of Verticillium dahliae isolates from cauliflower and other crops. Phytopathology 85:1105-1112. 1995.

WHITE, TJ., BRUNS, T., LEE, S. \& TAYLOR, J. Amplification and direct sequencing of fungal ribosomal RNA genes for phylogenetics. In: Innis, M.A., Gelgard, D.H., Sninsky, J.J. \& White, T.J. (Eds.) PCR Protocols: A Guide to Methods and Applications pp.315-322. Academic Press:New York. 1990. 